Н. П. Коваленко ${ }^{1}$

ORCID https://orcid.org/0000-0001-5998-1745

Н. О. Боброва ${ }^{2}$

ORCID https://orcid.org/0000-0002-1071-5697

Scopus Author ID 7004546261

О. В. Ганчо ${ }^{2}$

ORCID https://orcid.org/0000-0002-6983-4826

С. В. Зачепило 2

ORCID https://orcid.org/0000-0002-2194-0611 Scopus Author ID 57200449771

1Полтавська державна аграрна академія, Полтава

2 Українська медична стоматологічна академія, Полтава

\title{
МОТИВАЦІЯ СТУДЕНТІВ ЯК ЗАПОРУКА УСПІШНОГО ПРОФЕСІЙНОГО РОЗВИТКУ
}

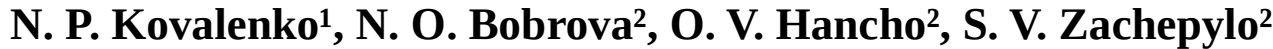 \\ 1 Poltava State Agrarian Academy, Poltava \\ ${ }^{2}$ Ukrainian Medical Stomatological Academy, Poltava

\section{STUDENTS’ MOTIVATION AS A PROMISE OF SUCCESSFUL PROFESSIONAL DEVELOPMENT}

\begin{abstract}
Анотація. Мотивація навчальної діяльності студентів стає в умовах сучасних перетворень в українській освіті однією з пріоритетних проблем. Актуальність теми дослідження обумовлена завданням подальшого підвищення якості навчання студентів в умовах сучасного суспільства, постійним оновленням змісту навчання, постановкою завдань формування у студентів потреби самостійного отримання знань і розвитку активної життєвої позиції.

Метою роботи було вивчення мотиваційної сфери студентів 2 та 3 курсів медичного факультету Української медичної стоматологічної академії з позиції формування основоположних мотивів для успішного професійного розвитку.

Ефективність навчального процесу безпосередньо пов’язана з мотивацією і стимулом оволодіння майбутньою професією. Основним фактором, що впливає на мотивацію до навчання студентів, є оволодіння знаннями, уміннями та навичками, які в подальшому сформують фундамент професійної діяльності. Підвищенню мотивації навчальної діяльності сприяють: спосіб засвоєння навчального матеріалу, його зміст, методи навчання; використання на кожному з етапів заняття проблемних мотивацій та завдань; застосування інтерактивних технологій.

Проведений нами аналіз показав, що серед студентів 2 та 3 курсів медичного факультету Української медичної стоматологічної академії переважають професійні мотиви навчання.

Студенти з більш високим середнім балом не виділяють профіль дисципліни як внутрішній мотив до навчання, зі зниженням середнього бала даний мотив починає переважати серед студентів-медиків.

Таким чином, навчання ефективніше діє, коли воно мотивоване, коли діяльність студентів збігається за спрямованістю та внутрішніми мотивами. В результаті успішною стає і професійна підготовка випускника вишу.
\end{abstract}

Ключові слова: мотивація; навчальна діяльність; студенти медичних факультетів; професійний розвиток; зацікавленість предметом.

Abstract. In the conditions of modern transformations in Ukrainian education, the motivation of students' educational activity is one of the priority problems. The relevance of the research topic is conditioned by the task of further improving the quality of students' education in the modern society, constant updating of the content of education, setting the tasks of forming the need for students to gain knowledge and develop an active life position.

The aim of the work was to study the motivational sphere of the 2nd and 3rd terms medical faculty students of the Ukrainian Medical Dental Academy from the point of view of basic motives for successful professional development formation.

The effectiveness of the educational process is directly related to the motivation and incentive to master the future profession. The main factor that influences students' motivation for learning is the acquisition of knowledge and skills that will further form the basis

(c) Н. П. Коваленко, Н. О. Боброва, О. В. Ганчо, С. В. Зачепило 
of professional activity. Improvement of the educational activity motivation is facilitated by: a way of educational material mastering, its content, methods of teaching; use of problem motivations and tasks at each stage of training; application of interactive technologies.

Our analysis showed that among the 2nd and 3rd terms medical faculty students of the Ukrainian Medical Dental Academy professional motives of study are prevailed. Students with a higher grade point average do not identify a discipline profile as an intrinsic motive for study, with a decline in grade point average this motive begins to prevail among medical students.

Thus, learning is more effective when it is motivated, when students' activities coincide with orientation and intrinsic motives. As a result, professional training of a graduate of the universities is successful.

Key words: motivation; educational activity; medical faculties students; professional development; interest in the subject.

Вступ. Мотивація як провідний фактор регуляції активності особистості, ї̈ поведінки та діяльності являє собою виключний інтерес для всіх людей.

Мотивація навчальної діяльності студентів стає в умовах сучасних перетворень в українській освіті однією з пріоритетних проблем. Вона, на думку $€$. П. Ільїна, $є$ сьогодні фундаментальною в психолого-педагогічній науці [5]. Це вимагає нових підходів до організації підготовки студентів вишу.

Діяльність викладача стає все більш складною. Оскільки методи стимуляції і навіть серйозне рейтингове заохочення не завжди приводять до досягнення мети [8], необхідно мати більш ефективні технології. Однією з таких, як показав досвід [2, $6,10], €$ мотивація навчальної діяльності студентів.

Для зарубіжних психологів характерним є одностороннє розуміння мотивації як суто енергетичного джерела активності. Цієї точки зору дотримуються 3. Фрейд, Браун, Фрієр, Фарбер та ін.

Вітчизняні психологи М. В. Матюхіна, С. Л. Рубінштейн, Б. В. Зейгарник, О.М.Леонтьєв та інші в розумінні і в самому визначенні мотивації виходять з положення про єдність динамічної і змістовної сторін мотивації [12].

С. Л. Рубінштейн писав: «Мотивація - це опосередкована процесом її відображення суб'єктивна детермінація поведінки людини світом. Через свою мотивацію людина вплетена в контекст дійсності» [11].

Під навчальною діяльністю в педагогіці розуміється не просто процес оволодіння якоюсь загальною або приватною навичкою, а мається на увазі систематичний процес засвоєння людиною певного кола знань і вмінь, який має більш-менш успішний характер.

У «Короткому словнику іноземних слів» $[7,9]$ поняття «мотивація навчальної діяльності» трактується як сукупність зовнішніх спонукань, індивідуальних прагнень і раціональних доводів, що визначають прийняття людиною аргументованого рішення про продовження навчальної діяльності; персоніфікований процес формування внутрішньої готовності до прийняття такого рішення, обумовленого соціальними обставинами й особистісни- ми якостями людини, що визначає і стимулює ії навчально-пізнавальну активність.

Існує кілька типів мотивації навчальної діяльності. Мотивація навчання (мотиви навчання) як діяльності, що свідомо здійснюється людиною, $\epsilon$ результатом як переробки тих впливів, які вона отримує з сімейного та широкого соціального середовища, так і освіти, свідомого чи малосвідомого відношення до цих впливів, пов'язаного з особливостями життєвих установок, прагнень, інтересів людини. Все це позначається на характері мотивації. Б. Ф. Ломов звернув увагу на те, що невмотивованої, так само і нецілеспрямованої діяльності просто не існує. Він писав: «Мотиви і мета утворюють свого роду «вектор» діяльності, що визначає її напрямок, а також величину зусиль, що розвиваються суб' єктом при її виконанні. Цей вектор виступає в ролі системоутворюючого фактора, який організовує всю систему психічних процесів і станів, що формуються в ході діяльності» [4].

О. В. Вільгаук стверджує, що однією з ефективних технологій роботи з мотивації навчальної діяльності зі студентами стає визначення їх пізнавальних, соціальних потреб і способів задоволення. У цьому випадку досить, на думку автора, використовувати поняття «внутрішній клієнт», оскільки зі студентами викладач працює як з клієнтами визначає їх мотивацію навчальної діяльності, намагається її активізувати і якісно змінювати згідно з соціальним замовленням суспільства [2].

Актуальність теми дослідження обумовлена завданням подальшого підвищення якості навчання студентів в умовах сучасного суспільства, постійним оновленням змісту навчання, постановкою завдань формування у студентів потреби самостійного отримання знань і розвитку активної життевої позиції.

Під мотивацією розуміють сукупність спонукаючих чинників, що визначають активність особистості, до яких належать мотиви, стимули, ситуативні чинники, потреби, що детермінують поведінку людини. Мотиваційна сфера будь-якої діяльності виконує ряд функцій: спонукаючу (викликає активність людини до діяльності); спрямовуючу 
(визначає характер мети в діяльності); регулюючу (визначає ціннісні орієнтації, мотиви діяльності).

Широко відомі зарубіжні мотиваційні теорії А. Маслоу, Д. МакКлелланда, Ф. Герцберга та ін. Так, А. Маслоу вважав, що мотивуючі потреби людини мають свою ієрархію. За Маслоу, базовими $€$ фізіологічні потреби. Далі, необхідна реалізація потреб у безпеці, потім важливі прагнення до спілкування, дружби, кохання і самоповаги. Вищий рівень потреб полягає в прагненні до самоактуалізації [10].

На жаль, у процесі навчання як студенти, так і викладачі припускаються помилок. Так, у процесі мотивування студентів викладачі намагаються дати максимальну кількість «голих знань», часто без обгрунтування їх необхідності. Проте доцільно пояснити, яким чином ці знання знадобляться студентові в майбутньому, оскільки в іншому випадку буде втрачено зацікавленість предметом.

Мета статті - вивчення мотиваційної сфери студентів 2 та 3 курсів медичного факультету Української медичної стоматологічної академії з позиції формування основоположних мотивів для успішного професійного розвитку.

Теоретична частина. Мотивація навчальної діяльності студентів є суттєво необхідною умовою для ефективного здійснення навчального процесу, оскільки негативне чи байдуже ставлення до навчання може бути причиною низької успішності або неуспішності студента.

Основним фактором, що впливає на мотивацію до навчання студентів, є оволодіння знаннями, уміннями та навичками, які у подальшому сформують фундамент професійної діяльності. У студентів, зацікавлених науковою діяльністю, виявляються мотиви саморозвитку та досягнень. Саме вони змушують багато працювати, розв’язувати складні завдання, займатися самоосвітою, долати труднощі для досягнення найвищих результатів.

У випадку низької мотивації викладачам доводиться використовувати різні способи стимулювання навчальної діяльності [3]. Оскільки молодь вступає до медичного вишу, щоб стати гарним спеціалістом у галузі медицини, викладач повинен довести, що його предмет буде необхідним у подальшій професійній діяльності. Крім того, необхідно не лише зацікавити предметом, а й відкрити для студента можливості практичного застосування отриманих знань. Для студента важливо бачити викладача своїм наставником, мати можливість звернутися до нього за допомогою під час навчального процесу, обговорити важливі і складні питання. Важливою для підвищення мотивації до навчання $є$ повага до студентів. Окремі викладачі вважають своїх студентів ледарями, хоча ті можуть просто не розуміти окремі теми.

Спілкування викладача зі студентом не повинно бути формальним, зверхнім або маніпулятивним. Воно повинно базуватися на глибокій зацікавленості до студента, визнанні самостійності його особистості.

Процес формування структури мотивів навчальної діяльності студента починається з перших днів перебування його у вищому навчальному закладі, але ефективність такого процесу може бути різною. В основному вона залежить від того, наскільки успішно і швидко вчорашній абітурієнт адаптується, долає труднощі, з якими він неминуче зустрічається, потрапляючи в незвичне для нього середовище. Дидактична новизна навчання у виші полягає у використанні інших, відмінних від школи, форм і методів організації навчального процесу, що включають подачу нового матеріалу, звітність, контроль тощо. У процесі постановки навчальних цілей студент зобов'язаний проявляти значно більшу самостійність, вміння врахувати і розподілити час, оптимально організувати роботу. Однак не всі можуть це оперативно зробити.

Ефективність навчального процесу безпосередньо пов’язана $з$ тим, наскільки високими є мотивація і стимул оволодіння майбутньою професією.

Для дослідження використовували методику вивчення мотивів навчальної діяльності студентів, модифіковану А. А. Реаном, В. А. Якуніним [1]. Зазначена методика визначала ефективність таких типів мотивації: 1) стати висококваліфікованим фахівцем; 2) отримати диплом; 3) успішно продовжити навчання на подальших курсах; 4) успішно вчитися, складати іспити на «добре» і «відмінно»; 5) постійно отримувати стипендію; 6) набути глибоких і міцних знань; 7) бути постійно готовим до чергових занять; 8) не запускати предмети навчального циклу; 9) не відставати від однокурсників; 10) забезпечити успішність майбутньої професійної діяльності; 11) виконувати педагогічні вимоги; 12) досягти поваги викладачів; 13) бути прикладом однокурсникам; 14) домогтися схвалення батьків і оточуючих; 15) уникнути засудження та покарання за погане навчання; 16) отримати інтелектуальне задоволення.

Проаналізувавши дані, отримані за допомогою модифікованої методики вивчення мотивів навчаль- 
ної діяльності студентів, ми виділили у студентівмедиків 5 основних мотивів навчальної діяльності: стати висококваліфікованим спеціалістом - 68,8 \%, отримати диплом - 64 \%, набути глибоких та міцних знань - 48 \%, отримати інтелектуальне задоволення - 43,2 \%, забезпечити успішність майбутньої професійної діяльності - 40 \%. Крім того, більшість опитаних студентів виділяє позитивним мотиваційним аспектом отримання схвалення і похвали від колег і викладачів.

Мотивація досить складний процес, що може мати різне спрямування. Внутрішня мотивація знаходиться в самій людині і є більш значимою, ефективною і необхідною формою мотивації. Зовнішня мотивація виходить від батьків, педагогів, суспільства.

Рівні розвитку внутрішньої мотивації до дисципліни «Мікробіологія, вірусологія та імунологія» відрізняються на 2-му і 3-му курсах медичного факультету. У 75 \% студентів 2-го курсу визначений високий рівень внутрішньої мотивації, у 25 \% студентів 2-го курсу - середній рівень внутрішньої мотивації. На 3-му курсі високий рівень мотивації виявлений у 37 \% студентів. Низький рівень мотивації серед всіх опитаних студентів не виявлений.

Проблема мотивації навчальної діяльності полягає не в тому, щоб змусити студента робити «як всі», а в тому, щоб знайти технології, що задовольняють соціальне замовлення суспільства - підготовку випускника вищого навчального закладу, конкурентоспроможного на ринку праці. Визнаючи цінність освіти, сучасне суспільство ставить під сумнів зміст освітніх програм. Дуже часто доводиться чути думки про непотрібність деяких тем, розділів і навіть дисциплін. Це досить спрощений підхід.

Підвищенню мотивації навчальної діяльності сприяє спосіб засвоєння навчального матеріалу. Зазвичай предмет засвоюється як послідовність окремих явищ. Кожне з розглянутих явищ викладач пояснює послідовно, дає готовий алгоритм дій 3 ними. Студенту нічого не залишається робити, як запам'ятати алгоритм і діяти відповідним способом. При такому засвоєнні предмета є небезпека втратити інтерес до нього.

Навпаки, коли вивчення предмета здійснюється через розкриття студентові сутності, що лежить в основі всіх явищ, то спираючись на цю сутність, він сам пізнає окремі явища і навчальна діяльність набуває для нього творчого характеру, тим самим викликаючи у нього зацікавленість предметом. При цьому мотивувати позитивне ставлення до вивчен- ня даного предмета може як його зміст, так і метод роботи з ним. В останньому випадку має місце мотивація процесом навчання.

Велике мотиваційне значення має порядок комплектування студентів у малі групи. Якщо студентів із нейтральною мотивацією до предмета об’єднати з тими, які не люблять даний предмет, то в результаті спільної роботи перші істотно підвищують свій інтерес до цього предмета. Якщо ж включити студентів із нейтральним ставленням до цього предмета в групу люблячих даний предмет, то ставлення у перших не змінюється.

Важливим у зацікавленості навчанням є відношення між мотивом і метою. Мета, поставлена викладачем, повинна бути зрозуміла студентові і стати його метою. Для перетворення мети в мотивицілі велике значення має усвідомлення студентом своїх успіхів, просування вперед.

На кожному з етапів заняття необхідно використовувати проблемні мотивації, завдання. Якщо викладач робить це, то зазвичай мотивація знаходиться на досить високому рівні. Важливо відзначити, що за змістом вона є пізнавальною, тобто внутрішньою.

Враховуючи зазначене, викладачі кафедри мікробіології, вірусології та імунології Української медичної стоматологічної академії широко використовують у своїй роботі проблемні мотивації, ситуаційні задачі. При цьому студентові пропонується алгоритм вирішення ситуаційної задачі.

Негативно впливають на мотивацію, згідно з опитуванням студентів-медиків, відсутність вільного часу і великі обсяги домашньої роботи.

Покращенню самостійної роботи студентів сприяють наявність та доступність навчально-методичного забезпечення. 3 метою поліпшення знань 3 мікробіології, вірусології та імунології кафедрою розроблено альбоми для виконання лабораторних робіт, збірники тестів, презентації лекцій, методичні вказівки.

Для підвищення мотивації у вивченні мікробіології, вірусології та імунологї і рівня засвоєння матеріалу на кафедрі застосовуються різні методи викладання і контролю знань, серед яких вирішення тестових та ситуаційних завдань, проведення ділових ігор, робота з дидактичними матеріалами, кейс-метод тощо. Для перевірки рівня засвоєння знань студентами на кафедрі обладнано комп’ютерний клас.

Застосування інтерактивних технологій підвищує зацікавленість студента у навчанні, формує 
здатність аналізувати отримані дані, застосовувати знання на практиці.

Найефективнішою технологією для забезпечення успіху студентів є процесуальна теорія очікування [5]. Стосовно мотивації до навчальної діяльності ця теорія виділяє важливість наступних взаємозв’язків: очікування співвідношення між витраченими зусиллями та отриманими результатами; очікування певної винагороди або заохочення у відповідь на досягнутий рівень результатів і передбачуваний ступінь задоволення. Відповідно до цієї теорії очікування, якщо значення будь-якого з цих факторів буде малим то, буде слабкою і мотивація навчальної діяльності в цілому.

Ефективною технологією мотивації навчальної діяльності студентів викладачами кафедри мікробіології, вірусології та імунології є організація на заняттях мотиваційного ефекту. Методом інтроспекції (самоспостереження) педагог може на досить високому рівні визначити мотивацію навчальної діяльності студентів. Для цього слід звернути увагу на осмисленість роботи (дій) студентів на заняттях при вивченні матеріалу, ступінь їх активності, самостійність виконання завдань, ставлення до особистих результатів, вміння працювати в групах, реагування на визнання та заохочення, вміння

\section{Список літератури}

1. Бадмаева Н. Ц. Влияние мотивационного фактора на развитие умственных способностей : монография / Н. Ц. Бадмаева. - Улан-Удэ, 2004. - 280 с.

2. Вильгаук О. В. Проблема мотивации в процессе становления студентов колледжа / О. В. Вильгаук // Профессиональная педагогика обучающихся колледжа : материалы науч.-практич. конф. - Магнитогорск : МГППК, 2007. - С. 67-69.

3. Гурова Н. А. Мотивация студентов к учебной и научной деятельности / Н. А. Гурова // Личность, семья и общество: вопросы педагогики и психологии : сб. ст. по материалам XLVII Междунар. науч.-практ. конф. Новосибирск : СибАК, 2014. - № 12 (47). - С. 102-105.

4. Зимняя И. А. Педагогическая психология : учебник для вузов / И. А. Зимняя. - 3-е изд., пересмотренное. М. : Московский психолого-социальный институт ; Воронеж : НПО «МОДЭК», 2010. - 448 с.

5. Ильин Е. П. Мотивация в учебной деяльности студентов : учеб. пособие для вузов / Е. П. Ильин. - СПб. : Питер, 2008. - 2840 с.

6. Карпова О. Л. Целостный подход как методологическая основа медиаобразования / О. Л. Карпова // Целостный подход к профессиональной подготовке выпускников вуза : монография / [О. Л. Карпова, А. Я. Найн, В. А. Анисимова и др.] ; ред. А. Я. Найн. - отримувати необхідну інформацію. В результаті викладач отримує певну картину зацікавленості студентів. Стають очевидними проблемні зони, з'являється можливість намітити шляхи зміни ситуації виховання мотивації навчальної діяльності.

Висновки та перспективи подальших досліджень. Проведений нами аналіз показав, що серед студентів 2 та 3 курсів медичного факультету Української медичної стоматологічної академії переважають професійні мотиви навчання.

Студенти з більш високим середнім балом не виділяють профіль дисципліни як внутрішній мотив до навчання, зі зниженням середнього бала даний мотив починає переважати серед студентівмедиків.

Навчання ефективніше діє, коли воно мотивоване, коли діяльність студентів збігається за спрямованістю та внутрішніми мотивами. В результаті успішною стає і професійна підготовка випускника вишу.

Оскільки в системі вищої освіти реалізуються два напрями діяльності, що впливають на мотивацію: виховна та навчальна робота, перспективним у подальшому є дослідження способів впливу цих складових на формування зацікавленості у студентів дисциплінами підготовки майбутнього лікаря.

Челябинск : Изд-во УралГУФК, 2015. - Глава V. С. $90-116$

7. Локшина С. М. Краткий словарь иностранных слов / С. М. Локшина. - 9-е изд., испр. - М., 1988. - 632 с.

8. Львов Л. В. Учебно-профессиональная компетентность: сущность, содержание и оценка : монография / Л. В. Львов. - Челябинск ; Магнитогорск : УралГУФК ; МаГУ, 2007. - 116 с.

9. Мотивація навчальної діяльності як запорука успішної професійної підготовки студента / Н. П. Коваленко, С. В. Пономаренко, Г. Д. Поспєлова, О. Л. Шерстюк // Сучасний підхід до викладання навчальних дисциплін в контексті підвищення якості вищої освіти : матеріали 50-ї наук.-метод. конф. викладачів і аспірантів (Полтава, ПДАА, 26-27 лютого 2019 р.). - Полтава, 2019. С. $13-16$.

10. Найн А. Я. Теоретические основы рефлексивного управления образовательным учреждением : монография / А. Я. Найн. - Челябинск : Уральская Академия, 2014. - 292 с.

11. Рубинштейн С. Л. Основы общей психологии / С. Л. Рубинштейн. - СПб. : Питер, 2000. - 712 с.

12. Якобсон П. М. Психологические проблемы мотивации поведения человека / П. М. Якобсон. - М. : Просвещение, 1969. - 317 с. 


\section{References}

1. Badmaeva, N.Ts. (2004). Vliyanie motivatsionnogo faktora na razvitye umstvennykh sposobnostey [The influence of motivational factor on the development of mental abilities]. Ulan-Ude [in Russian].

2. Vilhauk, O.V. (2007). Problema motyvatsii v protsesi stanovlennia studentiv koledzhu [The problem of motivation in the process of becoming college students]. Profesiina pedahohika navchaiutsia koledzhu: materialy nauk.-prakt. konf. - Professional pedagogy college students: Proceedings of the Scientific and Practical Conf. (pp. 67-69). Magnitogorsk: MHPPK [in Russian].

3. Gurova, N.A. (2014). Motivatsiya studentov k uchebnoy i nauchnoy deyatelnosti [Motivation of students for educational and scientific activities]. Lichnost, semya i obshchestvo: voprosy pedagogiki i psikhologii: sb. st. po materialam XLVII mezhdunar. nauch.-prakt. konf. Personality, Family and Society: Issues of Pedagogy and Psychology: A Collection of Articles based on Materials of XLVII International Scientific and Practical. Conf. Novosibirsk: SibAK, 12 (47), 102-105 [in Russian].

4. Zimniaya, I.A. (2010). Pedahohichna psykholohiia [Educational psychology]. (3 d ed.). Moscow: MPSY; Voronezh: NPO; MODEK [in Russian].

5. Ilin, Ye.P. (2008). Motyvatsiia v navchalnii diialnosti studentiv [Motivation in students'learning activities]. SaintPetersburg: Piter [in Russian].

6. Karpova, O.L. (2015). Tselostnyy podkhod kak metodologicheskaya osnova mediaobrazovaniya [Holistic approach as a methodological basis for media education]. Nayn, A.Ya. (Ed.). Tselostnyy podkhod $k$ professionalnoy podgotovke vypusknikov vuza [A holistic approach to the training of graduates]. Chelyabinsk: Izd-vo UralGUFK [in Russian].
7. Lokshyna, S.M. (1998). Korotkyi slovnyk inshomovnykh sliv [A short dictionary of foreign words]. (9d ed.). Moscow [in Russian].

8. Lviv, L.V. (2007). Navchalno-profesiina kompetentnist: sutnist, zmist i otsinka [Educational and professional competence: nature, content and assessment]. Cheliabinsk; Mahnytohorsk: UralHUFK; Mahu [in Russian].

9. Kovalenko, N.P., Ponomarenko, S.V., Pospielova, H.D., \& Sherstiuk, O.L. (2019). Motyvatsiia navchalnoi diialnosti yak zaporuka uspishnoi profesiinoi pidhotovky studenta [Motivation of educational activity as a pledge of successful student professional training]. Suchasnyi pidkhid do vykladannia navchalnykh dystsyplin $v$ konteksti pidvyshchennia yakosti vyshchoi osvity: materialy 50-i nauk.-metod. konf. vykladachiv i aspirantiv (26-27 liutoho 2019 r) - Modern Approach to Teaching Disciplines in the Context of Improving the Quality of Higher Education: Proceedings of 50-scientific Method. Conf. Teachers and Postgraduate Students (February 26-27, 2019). (pp. 13-16). Poltava: PGAA [in Ukrainian].

10. Nain, A.Ya. (2014). Teoreticheskie osnovy refleksivnogo upravleniya obrazovatelnym ucherezhdeniem: monografiya [Theoretical bases of reflexive management of an educational institution]. Chelyabinsk: Uralskaya Akademiya [in Russian].

11. Rubinshtein, S.L. (2000). Osnovy obshchey psikhologii [Fundamentals of general psychology]. Saint-Petersburg: Piter [in Russian].

12. Yakobson, P.M. (1969). Psikhologicheskie problemy motivatsii povedeniya cheloveka [Psychological problems of motivation of human behavior]. Moscow: Prosveshchenye [in Russian]. 